\title{
Biomedical Applications of Polyhydroxyalkanoates: The Future Polymer
}

\author{
Aditi Dhingra* \\ Amity Institute of Virology and Immunology (AIVI), Amity University, \\ Noida, Uttar Pradesh 201313, India \\ *Corresponding author
}

A B S T R A C T

\section{Keywords \\ Polyhydroxy alkanoates, \\ Biomedical apparatus, \\ Suture, Orthopaedic \\ devices, Implant patches, \\ Biodegradability, \\ Fracture fixation, \\ Plastics in healthcare \\ Article Info \\ Accepted: \\ 26 May 2020 \\ Available Online: \\ 10 June 2020}

Polyhydroxyalkanoates (PHA) are polymers, which are produced by microorganisms in the form of granules under unbalanced growth conditions. They are biocompatible, biodegradable and sustainable, which makes it suitable for synthesising biomedical apparatus. Devices such as sutures, orthopaedic devices, cardiovascular implants, implant patches can be prepared using different combinations of this polymer. The polymer and its composites being biodegradable and sustainable can take over the conventional plastics in near future. This article reviews the various aspects of polyhydroxyalkanoates in the field of biomedicine and concludes PHA as the future polymer.

\section{Introduction}

Conventional plastics are organic polymers of high molecular mass. They are usually synthetic, however, being lightweight, flexible, stable and highly durable, it is used in numerous packaging applications, constructional materials, baby products and even in the field of medicine. However, plastic is known to cause various health problems, also being non-biodegradable, it negatively affects the soil, groundwater, water table and eventually the ecosystem. After years of research, PHA was introduced. PHA stands for Polyhydroxyalkanoates. PHA is a family of carbon neutral polymers, obtained from microorganisms. PHA was first discovered in 1926 by Lemogine in Bacillus megaterium, in the form of poly (3hydroxybutyrate)[PHB] (Chen, 2009).

PHA are referred to as green plastics, being environmental friendly, when compared to the conventional plastic under environmental conditions (in vivo). PHA can be synthesized by over $30 \%$ of soil inhabiting bacteria. PHA has no harmful, acute and chronic health effects. PHA is a polymer, consisting of 600- 
35000 (R) hydroxy fatty acid monomer units, with an alkyl group attached to it. PHA also exist in the form of homopolymer, random copolymer and block polymers, depending on the bacterial species and growth conditions. Out of these monomeric units 150 are identified. Monomers are classified as short, medium and long chain based on the number of carbon atom present. The short chain consists of 5 or less carbon atoms. The medium chain consists of 5-14 carbon atoms and the long chain consists of more than 14 carbon atoms (Table 1). PHA can be synthesized by either chemical means or biological approaches. Biosynthesis of PHA leads to much higher molecular weight compared with that achieved with chemical methods. Identification of PHA monomers have increased tremendously through the creation of GMO's to produce PHA with specialised functional group (from non PHA strains). They are stored as energy storage material by various microorganisms. PHA promotes long term survival of bacteria under nutrient scarce conditions by acting as carbon and energy resource. To date more than 90 genera of both gram positive and gram negative bacteria have been identified as PHA producers under both aerobic and anaerobic conditions. Bacteria stores PHA within cytoplasm as granules, size 0.2- 0.5 micro meter.

There are two groups of bacteria: ( i ) Bacteria requires limited nutrients (Phosphorous, Nitrogen, Oxygen and Magnesium) and do not accumulate PHA, during growth phase (Table 3). Example: Pseudomonas oleovorans, Pseudomonas putida. (ii) Bacteria that accumulate PHA during growth phase and do not require any nutrient conditions. Example: Escherichia coli. Increase in carbon/nitrogen ratio promotes PHA accumulation while reverse of it is responsible for cell growth. PHA acts as a potential anti HIV drug, anti cancer drug, antibiotics (Chen and Wu, 2005).

\section{Properties}

(A) Biodegradable

(B) Biocompatible

(C) Chemically diverse

(D) Can be manufactured from renewable carbon source

(E)Recyclable

(F) No pollution

(G) Reduce landfill requirement

(H) Sustainable

(I) Resistant to moisture

(J) Insoluble in water

(K) Resistant to UV

(L) Resistant to heat

(M) Resistant to osmotic shock

(N) Behave as piezoelectric material

(O) Soluble in chloroform and other chlorinates solvents

(P) Melting temperature $\left(40^{\circ}-180^{\circ}\right)$

(Chen, 2009) (Table 2)

\section{Applications}

Cardiovascular: One of the major use of PHA's has been in the development of cardiovascular products.

PHA in drug delivery: Aims at increasing the availability of drugs as well as controlled release of drugs with respect to time and space. Example: PHB and its polymers are used for the preparation of microspheres and nanoparticles to deliver a range of drug PHBV rods and discs are used to deliver antibiotics. Polyhydroxyoctanoate were evaluated as drug electing stents to reduce the possibility of arterial blockage.

PHB - drug conjugates: One problem with PHB drug delivery system is the rapid release of drugs. Conjugation of drug to PHB polymer could increase release time and availability. 
PHB or PHBV as implant patches: Treat defects in the gastrointestinal tract (local resection and closure of defect by suture). Implant needs to meet certain criteria:

Should not cause inflammatory response.

Should be biocompatible.

Should support wound healing/tissue regeneration.

Patch should disappear after serving their purpose (Biodegradable).

PHBHHX as bone tissue engineering materials: PHBHHX has the best performance on attachment, proliferation of bone marrow cells.

PHA as biodegradable drug carriers: Biocompatible PHA with controlled degradation rates was described by Martin et al., Required criteria:

Increased porosity. Exposed surface area.

Degrade within desirable time frame under physiological conditions.

Anti-ageing products: PHA's are humectants, meaning they can retain moisture, and hydrate the skin by gently exfoliating.

Extraction: Polyhydroxy alkanoate are accumulated as granules in the cytoplasm of bacterial cells. Hence, in order to extract PHA, some major requirements are:

Collection and subculturing of bacterial cells on suitable nutrient media

Microscopic observations

Nitrogen estimation

The content and composition of PHA and there polymers are influenced by the strains of microorganisms.
Some of the widely used extraction methods are:

Extraction of PHA from bacteria using chloroform

Harvest bacterial cells (pellet)

Wash pellet with little volume of chloroform

Add $10 \mathrm{ml}$ chloroform

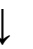

Heat while shaking at $60^{\circ} \mathrm{C}$ (pellet disolves)

Cell membrane distrupt and PHA comes out

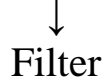

Evaporate by the method of distillation

Add chilled methanol $\rightarrow$ PHA film obtained

(Valid for both gram positive and gram negative bacteria with $95 \%$ extraction capacity of total PHA)

\section{Extraction of PHA in its natural state}

A less drastic method of extraction leaves the PHA in a form similar to that found in bacterial cells. In such a method, bacterial cells are treated with detergents. Detergents degrade the cells thereby releasing PHA and denaturing most other cell components.

The process of purification is completed by a brief treatment with bleach (oxidizing agent), capable of breaking chemical bonds in the polyester, lowering its molecular weight.

(C) Digestion method: This method involves the digestion of the cellular materials surrounding the PHA granules. Chemical methods may be chemical digestion method or enzymatic digestion method. 
Table.1

\begin{tabular}{|l|l|l|}
\hline $\begin{array}{l}\text { Carbon } \\
\text { number }\end{array}$ & R. Group & Polymer \\
\hline C4 & Methyl & Poly(3-hydroxybutyrate) \\
\hline C5 & Ethyl & Poly(3-hydroxyvalerate) \\
\hline C6 & Propyl & Poly(3-hydroxyhexanoate) \\
\hline C7 & Butyl & Poly(3-hydroxyheptanoate) \\
\hline C8 & Pentyl & Poly(3-hydroxyoctanoate) \\
\hline C10 & Hexyl & Poly(3-hydroxynonanoate) \\
\hline C11 & Heptyl & Poly(3-hydroxydecanoate) \\
\hline C12 & Octyl & Poly(3-hydroxyundecanoate) \\
\hline C13 & Nonyl & Poly(3-hydroxydodecanoate) \\
\hline C14 & Decyl & Poly(3-hydroxytridecanoate) \\
\hline C15 & Undecyl & Poly(3-hydroxytetradecanoate) \\
\hline C16 & Dodecyl & Poly(3-hydroxypentadecanoate) \\
\hline & Tridecyl & Poly(3-hydroxyhexadecanoate) \\
\hline
\end{tabular}

(Chen, 2009)

Table.2

\begin{tabular}{|l|l|l|l|l|}
\hline & Temperature $\left(^{\circ}\right)$ & Density & Crystallinity (\%) & $\begin{array}{l}\text { Elongation to } \\
\text { break (\%) }\end{array}$ \\
\hline PHB & $170-180$ & 1.24 & $60-80$ & 328 \\
\hline PP & 176 & - & 50 & 400 \\
\hline PHBV & 169.8 & 1.20 & $30-80$ & UPTO 100 \\
\hline $\begin{array}{l}\text { P(3HB-co- } \\
\text { 3HV) }\end{array}$ & 145 & - & 56 & 50 \\
\hline PHBHHx & $95-150$ & - & $10-50$ & UPTO 400 \\
\hline $\begin{array}{l}\text { P(3HB-co- } \\
\text { 4HB) }\end{array}$ & 150 & - & 43 & 444 \\
\hline
\end{tabular}


Table.3 Types of PHA and the microorganisms from which they are extracted

\begin{tabular}{|c|c|c|c|}
\hline Microorganisms & Source & Applications & Reference \\
\hline 1. Bacillus megaterium & $\mathrm{P}(3 \mathrm{HB})$ & $\begin{array}{l}\text { Sutures } \\
\text { Stents } \\
\text { Drug delivery system }\end{array}$ & $\begin{array}{l}\text { (Gouda et al., } \\
\text { 2001) }\end{array}$ \\
\hline 2. Bacillus cereus & PHB & Drug carrier & $\begin{array}{l}\text { (Pradhan et al., } \\
\text { 2018) }\end{array}$ \\
\hline 3. Alcaligenes eutrophus & PHB-co-PHV & Bone implants & $\begin{array}{l}\text { (Ryu et al., 1997) } \\
\text { (Luklinska and } \\
\text { Schluckwerder, } \\
\text { 2003) }\end{array}$ \\
\hline 4. Aeromonas caviae & $\mathrm{P}(3 \mathrm{HB}-\mathrm{co}-3 \mathrm{HHx})$ & Sutures & $\begin{array}{l}\text { (Ali and Jamil, } \\
\text { 2016) }\end{array}$ \\
\hline $\begin{array}{l}\text { 5. Pseudomonas strain } \\
\text { GP4BH1 }\end{array}$ & PHB-co-PHO & $\begin{array}{l}\text { Sutures } \\
\text { Implant patches }\end{array}$ & $\begin{array}{l}\text { (Muhammadi et } \\
\text { al., 2015) }\end{array}$ \\
\hline $\begin{array}{l}\text { 6. Photobacterium } \\
\text { leiognathi }+ \text { Vibrio harveyi }\end{array}$ & $\begin{array}{l}\mathrm{PHB}(\text { major } \\
\text { component })+\mathrm{PHV}+ \\
\mathrm{HHx}(\text { minor } \\
\text { component })\end{array}$ & $\begin{array}{l}\text { Bone implants } \\
\text { Sutures }\end{array}$ & $\begin{array}{l}\text { (Boyandin et al., } \\
\text { 2008) }\end{array}$ \\
\hline $\begin{array}{l}\text { 7. Pseudomonas putida } \\
\text { KT2442 }\end{array}$ & P(HB-HHx-HO) & $\begin{array}{l}\text { Implant patches } \\
\text { Sutures }\end{array}$ & $\begin{array}{l}\text { (Ouyang et al., } \\
\text { 2007) }\end{array}$ \\
\hline $\begin{array}{l}\text { 8. Alcaligenes latus } \\
\text { DSM1124 }\end{array}$ & $\mathrm{P}(3 \mathrm{HB})$ & $\begin{array}{l}\text { Drug delivery } \\
\text { systems }\end{array}$ & (Yu et al., 1999) \\
\hline $\begin{array}{l}\text { 9. Burkholderia } s p \text {. } \\
\text { USM(JCM 15050) }\end{array}$ & $\begin{array}{l}\mathrm{P}(3 \mathrm{HB}) \text { based } \\
\text { monomer } \\
\text { Poly-3-hydroxy-4- } \\
\text { methylvalerate }\end{array}$ & $\begin{array}{l}\text { Medical implants } \\
\text { Dental materials }\end{array}$ & (Lau et al., 2010) \\
\hline $\begin{array}{l}\text { 10. Comamona } \\
\text { testosteroni }\end{array}$ & MCL-PHA & Wound dressing & $\begin{array}{l}\text { (Thakor et al., } \\
\text { 2005) }\end{array}$ \\
\hline 11. Cupriavidus necator & $\mathrm{P}(3 \mathrm{HB})$ & sutures & $\begin{array}{l}\text { (Agustín } \\
\text { Martinez et al., } \\
\text { 2015) }\end{array}$ \\
\hline $\begin{array}{l}\text { 12. Cupriavidus necator } \\
\text { H16 }\end{array}$ & $\mathrm{P}(3 \mathrm{HB}-\mathrm{co}-3 \mathrm{HV})$ & Wound management & (Ng et al., 2010) \\
\hline $\begin{array}{l}\text { 13. Cupriavidus necator } \\
\text { DSM } 545\end{array}$ & $\mathrm{P}(3 \mathrm{HB})$ & Wound management & (Berezina, 2013) \\
\hline $\begin{array}{l}\text { 14. Pseudomonas } \\
\text { aeruginosa IFO3924 }\end{array}$ & MCL-PHA & $\begin{array}{l}\text { Wound dressing and } \\
\text { management }\end{array}$ & (Hori et al., 2002) \\
\hline $\begin{array}{l}\text { 15. Pseudomonas } \\
\text { aeruginosa } \mathrm{N} \otimes \mathrm{B} 40045\end{array}$ & MCL-PHA & Wound dressing & $\begin{array}{l}\text { (Fernández et al., } \\
\text { 2005) }\end{array}$ \\
\hline $\begin{array}{l}\text { 16. Thermus thermophilus } \\
\text { HB8 }\end{array}$ & $\begin{array}{l}\text { P(3HV-co-3HHp-co- } \\
\text { 3HN-co-3HV) }\end{array}$ & $\begin{array}{l}\text { Sutures } \\
\text { Stents }\end{array}$ & $\begin{array}{l}\text { (Pantazaki et al., } \\
\text { 2009) }\end{array}$ \\
\hline
\end{tabular}


Table.4

\begin{tabular}{|c|c|c|c|}
\hline Year & Name of Scientist & Type of Device & Problems \\
\hline $\mathbf{1 8 9 5}$ & Lane & Metal Plates & Corrosion \\
\hline 1909 & Lambotte & $\begin{array}{c}\text { Round and tapered } \\
\text { metal plate }\end{array}$ & $\begin{array}{c}\text { Corrosion and } \\
\text { insufficient strength }\end{array}$ \\
\hline 1912 & Sherman & Metal plates & $\begin{array}{c}\text { Corrosion and } \\
\text { insufficient strength }\end{array}$ \\
\hline 1948 & Egger & Metal plate held by & $\begin{array}{c}\text { Unstable and } \\
\text { screws } \\
\text { structurally weak }\end{array}$ \\
\hline 1949 & Danis & $\begin{array}{c}\text { Compression metal } \\
\text { plate (coapteur) }\end{array}$ & $\begin{array}{c}\text { Corrosion and } \\
\text { inflammation }\end{array}$ \\
\hline 1956 & Bagby and Janes & $\begin{array}{c}\text { Plates with oval } \\
\text { holes that allow } \\
\text { inter-fragmentary } \\
\text { compression during } \\
\text { screw tightening }\end{array}$ & $\begin{array}{c}\text { Corrosion and } \\
\text { inflammation }\end{array}$ \\
\hline & & & \\
\hline
\end{tabular}

Fig.1

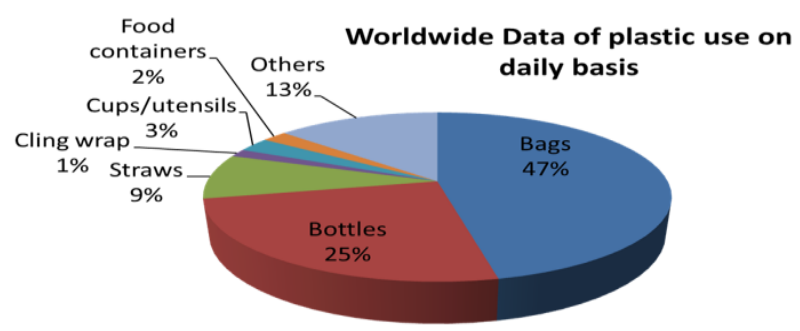

Fig.2

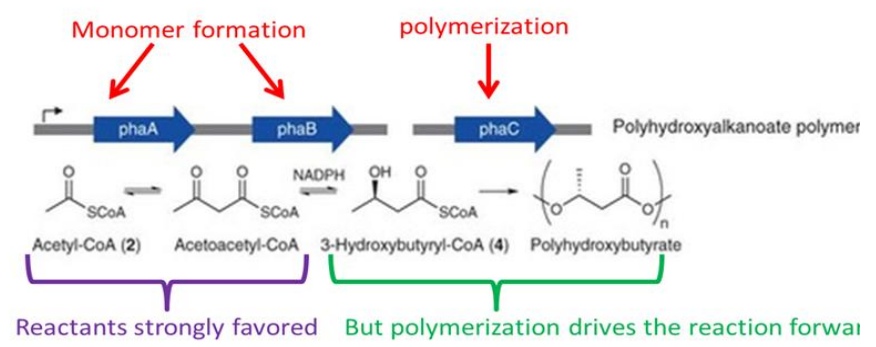

Reaction mechanism of PHAs pathway 


\section{Wound dressing}

Wound dressing is a technique that may or may not be surgical. This technique involves providing the wound with aseptic or sterilized environment in order to prevent undue contamination of the wound. This technique is basically employed in areas where healing of the wound by itself is difficult and painful. In some cases, wound dressing is employed to apply medication to the wounded area.

\section{Types of dressings}

Dressings may be of the following types:

- Sutures

- Staples

- Transparent adhesives

- Clips

Suture: is a largest group of medical apparatus used in wound healing, commonly known as stitches. They may be natural or synthetic. Sutures are used mainly to treat vascular wounds and tissue wounds. Their main purpose is wound closure, it involves a needle attached with a thread, however the size, shape and materials have been drastically evolved with new developments over the years. The sutures are secured with a surgical knot at the end of the wound.

\section{Characteristics:}

Biologically inert

Antimicrobial properties

- ease in handling (Pliable)

- have high tensile strength

- non allergic to host

- non carcinogenic

- should be absorbed after serving its function

- must be able to dissolve in body fluids (absorbable sutures)
History: suturing as a technique is not new, this procedure is now known for ages. Physicians have been using suture for thousands of years now. However, with the advancement in the medical and surgical fields, the material used for this procedure has drastically evolved since time immemorial. Ancient records show the use of hair, linen, grass, pig bristles, cotton, silk and animal gut to close wounds, but today we rarely see such suture.

Classification: sutures are classified into two categories:

1. On the basis of origin

2. On the basis of absorbability

1. On the basis of origin: sutures are further classified as natural and synthetic.

- Natural suture: are obtained directly from the nature. For example: hair, grass, cotton, pig bristles and dried animal gut (cats).

- Synthetic suture: are those that are artificially synthesised by humans, to serve the purpose of wound dressing. For example: silk, nylon, polyester, stainless steel.

2. On the basis of absorbability: sutures are further classified as absorbable and nonabsorbable.

- Absorbable suture:_are those, that have the tendency to dissolve themselves in the body fluids, after serving its purpose. The duration in which the suture dissolves itself may vary from 10 days to 8 weeks, depending upon the severity of wound.

For example: catgut suture, Poly-glycolic acid suture, collagen, poly-lactic acid suture etc.

- Non- absorbable suture: are those, that lack the tendency to dissolve themselves in body fluids and thus have to be removed after wound closure. 
For example: nylon, polyester, stainless steel, polypropylene etc. (Pillai and Sharma, 2010).

Selection of suture material: Selection of suture material is a complicated process. Today we have a large variety of suture mastering a few properties over the others. No one suture is ideal for all types of surgeries. The tensile strength, its absorption rate, its flexibility and the ease to knot are some of the important considering factors for a surgeon. If suture are not selected judiciously, it may increase the complications of a surgery and also may delay the healing process.

Polyhydroxyalkanoates in suture: For a material to be used as suture, it must not only be biocompatible but also biodegradable. PHA's are polyester, produced by microorganisms. The most common PHA used in suture production is PHB poly(3hydroxybutyrate) and its related copolymer PHBV poly(3HB-co-3HV).

Both these polymers are biocompatible i.e. are non-toxic to the host and does not produce host immune reactions such as inflammation, necrosis, tumor formation when incorporated in the host body.

Both PHB and PHBV are slow biodegrading polymers and undergo anaerobic biodegradation in the form of sediments, whereas PGA (Poly-glycolic acid) which is still in use as suture is a bulk degrading polymer. PGA being a bulk degrading polymer, has the tendency to accumulate in various parts of the body, since bulk degradation is difficult to remove from the host system. This accumulation of PGA polymer is toxic to the surrounding tissue in the long run. But the slow degrading PHB and PHBV does not get accumulated in the surrounding tissues and is removed from the host system after completing its function.
PHB has a high tensile strength of $40 \mathrm{MPa}$, which makes it suitable for suture preparation as it exhibits the strength necessary for tissue joining, thereby healing the wound.

Presence of foreign materials in wound is known to enhance the infection in wounds. PHB and PHBV do not show any reaction with the foreign material, hence prevent the spread of infection. Another approach to avoid wound infection is the production of antimicrobial suture. This can be done by incorporating silver metal on the surface of PHB or PHBV suture.

Thus, PHB and PHBV have several advantages over the most commercially available sutures. However, the commercialization of PHA as suture is curbed by the high cost of its production.(Dennis et al., 2016)

Drug delivery systems: are artificially engineered medical apparatus used for targeted delivery or control release of the drug. The purpose of the drug delivery system is to control the rate at which drug is released and the site where it is released. Drug delivery systems are of various types, they may be in the form of tablets, nanoparticles, implant patches. Here we are going to focus majorly on the implant patches.

Implant patches: An implant is a device used to deliver drug at a particular site of action or can be used to replace a defect in a biological structure or support a damaged biological structure.

For example: Contraceptive patch: it is a transdermal patch, safe and reliable. When placed on the skin of belly, upper arm, butt or lower back, it releases a hormone that prevents pregnancy. 
Implant patches not only have their applications in contraception but also in cosmetics, sensory and neurological disorder, cardiovascular mis-function, orthopaedics.

\section{Properties}

- Biocompatible

- Biodegradable

- Non allergic to host

- Non reactive in host system

- Non carcinogenic

- Anti microbial

Types: three major types of implant patches are commercially used:

i. Stainless steel

ii. Cobalt- chromium alloy

iii. Titanium based alloy

\section{Challenges/Complications}

i. Stainless steel patches are prone to corrosion, when subjected in the host body. As a result may cause foreign body response, pain, rejection, inflammation (Table 4).

ii. Cobalt-chromium alloy implants: some patients are allergic to metal implants. Introduction of this type of an alloy in such patients can cause an aggressive form of skin cancer in the host, which is now known as the Marjolin's ulcer. Major symptom includes errythema, rash, eczema, swelling and pain.

iii. Titanium based implant: are generally used in orthopaedic devices and oral implants. The accumulation of titanium ions or particulate titanium in the nearby tissues can induce allergic type 1 to 4 reactions.

\section{PHA as implants}

PHB based implant patches for gastrointestinal tract on rat model, it was observed that neither an inflammatory response nor fibrosis was observed with the introduction of this polymer into the host, unlike that observed with the commercially available metal implants.

Similarly, PHBV based implant patches for wound healing in dogs, aged 12 weeks. the dogs were studied until the age of 25 weeks. It was found that it took approximately 7 weeks for complete wound closure and with no observations of foreign body immune response, inflammation or tissue fibrosis. (Chen and $\mathrm{Wu}, 2005$ )

PHB can be used as transdermal patches as it is relatively resistant to hydrolytic degradation and it posses water insolubility, shows great resistance to ultra violet radiations, has high melting point of $175^{\circ} \mathrm{C}$, is non toxic to both human and animal host.

Orthopaedic devices: is a medical device, used to correct or treat skeletal deformities in humans and animals.

Fracture fixation: is a term used to refer the stabilization of a broken bone or in simple words when a bone breaks, its pieces get aligned in an unstable manner, which needs to be fixed back to its original location in order to ensure mobility.

There are various devices, commonly referred to as fracture fixation devices which are commercially available and are used to stabilize a broken bone. These devices are of various shapes and sizes and are used accordingly. These include pins, rods, screws, nails, bone plates and many others.

\section{Properties}

- Biocompatible

- High modulus of elasticity

- Non corrosive

- Non allergic 
- Ductile

- Malleable

- Stiff

History: Internal fixation of fractures is not a new technique, it has been practiced for more than 100 years now. However, the material used for these devices has changed overtime, due to some major complications.

By the mid 20th century, titanium and stainless steel were used to prepare such devices. However these materials still have disadvantages.

Metals have been used in fracture fixation since time immemorial, owing to its high stiffness, strength and low cost, despite the biological responses they produce when introduced into the host system.

Many of the components of stainless steel devices such as chromium $(\mathrm{Cr})$, cobalt $(\mathrm{Co})$, iron $(\mathrm{Fe})$ and nickel $(\mathrm{Ni})$ are known to cause toxicity and effect variety of systems of the host, such as the vascular, immune, excretory, reproductive and nervous system. Also Ni ions are known to cause aggressive skin allergies. Moreover, $\mathrm{Ni}, \mathrm{Cr}$ and $\mathrm{Co}$ are known to interfere the DNA repair mechanism, as a result responsible for altered gene expression. High levels of $\mathrm{Cr}$ ions are known to cause hepatocellular necrosis. $\mathrm{Ni}$ ions have been shown to increase the mortality due to cardiovascular diseases.

Also $\mathrm{Cr}$ ions exposure to mice has shown a decrease sperm count and induced sperm abnormalities, as well as reducing the number of ovarian follicles and ova in mice.

Titanium and titanium based alloys gets degraded into titanium ions or particulate titanium when subjected to friction. The accumulation of these titanium ions is toxic for the surrounding tissues and might cause toxicity and induce foreign body response, inflammation, tissue necrosis and unwanted pain at the site (Hayes and Richards, 2010).

Complications: Introduction of metals as fixation device into the host may lead to a number of complications such as necrosis, pain, inflammation and may induce a host immune response. Nevertheless, metals are strong and cost effective but are toxic to the host, which may lead to the surgical removal of the entire organ if its toxicity spreads to the neighbouring tissues.

\section{Alternative: PHA as fracture fixation device}

PHB poly(3-hydroxybutyrate) and its copolymer PHBV poly(3-hydroxybutyrateco-3-hydroxyvalerate) can replace the metals in fracture fixation. These are natural polymers, synthesised by various different types of bacteria.

PHB and PHBV are an interesting biopolymer having mechanical strength in compression of $62 \mathrm{MPa}$, which is about the same order of magnitude of several bones in human body and thus can be used in the fracture fixation. Other remarkable properties of this biopolymer is its biocompatibilty, shows no host immune response being non-toxic to the host, being water insoluble it can be introduced into the host system without a second thought. Has high modulus of elasticity which makes it strong and replaceable to the metal fixation devices.

Plastics in healthcare industry: Plastic is a dynamic material, development of which has revolutionized almost all the industries. But when we precisely look at the healthcare industry, plastic is almost everywhere; from a small syringe to meter long catheters and large medical packaging. This diversity is observed because of its tendency to be 
moulded in any shape and any size. Its light weight, durability, low cost and transparency makes it ideal for the healthcare industry. Some of the most widely used plastics in healthcare are PVC (Poly-vinyl chloride), PE (Polyethylene), PP (Polypropylene), PS (Polystyrene) and PET (Polyethylene terephthalate).

Some plastic material in healthcare industry:

- Syringes

- Gloves

- Coats

- Mask

- Hair and shoe caps

- Disposal bags

- Catheter

- Cannula

- Dropper

Plastics have made the healthcare industry smooth

\section{Advantages}

i. Cost effective: plastic production is cost effective. Since the healthcare industry demands large number of plastic based equipments, it becomes difficult to used ceramic, glass or metal equipments because of its high cost and maintenance.

Because of its cost effective nature, single use syringes, gloves and various other equipments are available commercially nowadays, this in turn prevents the spread of various infectious diseases.

ii. Low weight: The low weight of plastic equipment ensures its easy handling.

iii. Can be moulded into any shape: and thus has various applications.

\section{Disadvantages}

- Plastic disposal is still a problem. Its non biodegradable nature does not allow its degradation instead results in the release of toxic fumes harmful for both humans and animals.

- Its accumulation in the soil results in release of some toxic substances, thereby polluting the soil as well as the water table.

- Can be carcinogenic

\section{References}

Agustín Martinez, G., Bertin, L., Scoma, A., Rebecchi, S., Braunegg, G., and Fava, F. (2015). Production of polyhydroxyalkanoates from dephenolised and fermented olive mill wastewaters by employing a pure culture of Cupriavidus necator. Biochemical Engineering Journal, 97, 92-100. https://doi.org/10.1016/j.bej.2015.02.01 5

Ali, I., and Jamil, N. (2016). Polyhydroxyalkanoates: Current applications in the medical field. Frontiers in Biology, 11(1), 19-27. https://doi.org/10.1007/s11515-016$1389-\mathrm{z}$

Berezina, N. (2013). Novel approach for productivity enhancement of polyhydroxyalkanoates (PHA) production by Cupriavidus necator DSM 545. New Biotechnology, 30(2), 192-195.

https://doi.org/10.1016/j.nbt.2012.05.00 2

Boyandin, A., Kalacheva, G. S., Medvedeva, S., Rodicheva, E., and Volova, T. G. (2008). Luminous bacteria as producers of polyhydroxyalkanoates. Macromolecular Symposia, 269(1), 1722. https://doi.org/10.1002/masy.20085090 
4

Chen, G.-Q. (2009). Plastics Completely Synthesized by Bacteria: Polyhydroxyalkanoates. Plastics from Bacteria: Natural Functions and Applications, 14(12), 17-37. https://doi.org/10.1007/978-3-64203287_5_2

Chen, G.-Q., and Wu, Q. (2005). The application of polyhydroxyalkanoates as tissue engineering materials. Biomaterials, 26(33), 6565-6578. https://doi.org/10.1016/j.biomaterials.20 05.04.036

Dennis, C., Sethu, S., Nayak, S., Mohan, L., Morsi, Y. Y., and Manivasagam, G. (2016). Suture materials - Current and emerging trends. Journal of Biomedical Materials Research Part A, 104(6), 1544-1559.

https://doi.org/10.1002/jbm.a.35683

Fernández, D., Rodríguez, E., Bassas, M., Viñas, M., Solanas, A. M., Llorens, J., Marqués, A. M., and Manresa, A. (2005). Agro-industrial oily wastes as substrates for PHA production by the new strain Pseudomonas aeruginosa NCIB 40045: Effect of culture conditions. Biochemical Engineering Journal, 26(2-3), 159-167. https://doi.org/10.1016/j.bej.2005.04.02 2

Gouda, M. K., Swellam, A. E., and Omar, S. H. (2001). Production of PHB by a Bacillus megaterium strain using sugarcane molasses and corn steep liquor as sole carbon and nitrogen sources. Microbiological Research, 156(3), 201-207. https://doi.org/10.1078/0944-501300104

Hayes, J., and Richards, R. (2010). The use of titanium and stainless steel in fracture fixation. Expert Review of Medical Devices, 7(6), 843-853. https://doi.org/10.1586/erd.10.53
Hori, K., Marsudi, S., and Unno, H. (2002). Simultaneous production of polyhydroxyalkanoates and rhamnolipids by Pseudomonas aeruginosa. Biotechnology and Bioengineering, 78(6), 699-707. https://doi.org/10.1002/bit.10248

Lau, N.-S., Chee, J.-Y., Tsuge, T., and Sudesh, K. (2010). Biosynthesis and mobilization of a novel polyhydroxyalkanoate containing 3hydroxy-4-methylvalerate monomer produced by Burkholderia sp. USM (JCM15050). Bioresource Technology, 101(20), 7916-7923. https://doi.org/10.1016/j.biortech.2010. 05.049

Luklinska, Z. B., and Schluckwerder, H. (2003). In vivo response to HApolyhydroxybutyrate/polyhydroxyvalera te composite. Journal of Microscopy, 211(2), 121-129. https://doi.org/10.1046/j.13652818.2003.01204.x

Muhammadi, Shabina, Afzal, M., and Hameed, S. (2015). Bacterial polyhydroxyalkanoates-eco-friendly next generation plastic: Production, biocompatibility, biodegradation, physical properties and applications. Green Chemistry Letters and Reviews, 8(3-4), 56-77. https://doi.org/10.1080/17518253.2015. 1109715

Ng, K.-S., Ooi, W.-Y., Goh, L.-K., Shenbagarathai, R., and Sudesh, K. (2010). Evaluation of jatropha oil to produce poly(3-hydroxybutyrate) by Cupriavidus necator H16. Polymer Degradation and Stability, 95(8), 13651369.

https://doi.org/10.1016/j.polymdegradst ab.2010.01.021

Ouyang, S.-P., Luo, R. C., Chen, S.-S., Liu, Q., Chung, A., Wu, Q., and Chen, G.-Q. (2007). Production of 
Polyhydroxyalkanoates with High 3Hydroxydodecanoate Monomer Content by fadB and fadA Knockout Mutant of Pseudomonas putida KT2442. Biomacromolecules, 8(8), 2504-2511. https://doi.org/10.1021/bm0702307

Pantazaki, A. A., Papaneophytou, C. P., Pritsa, A. G., Liakopoulou-Kyriakides, M., and Kyriakidis, D. A. (2009). Production of polyhydroxyalkanoates from whey by Thermus thermophilus HB8. Process Biochemistry, 44(8), 847-853.

https://doi.org/10.1016/j.procbio.2009.0 4.002

Pillai, C. K. S., and Sharma, C. P. (2010). Review Paper: Absorbable Polymeric Surgical Sutures: Chemistry, Production, Properties, Biodegradability, and Performance. Journal of Biomaterials Applications, 25(4), 291-366. https://doi.org/10.1177/0885328210384 890

Pradhan, S., Dikshit, P. K., and Moholkar, V. S. (2018). Production, ultrasonic extraction, and characterization of poly (3-hydroxybutyrate) (PHB) using Bacillus megaterium and Cupriavidus necator. Polymers for Advanced
Technologies, 29(8), 2392-2400. https://doi.org/10.1002/pat.4351

Ryu, H. W., Hahn, S. K., Chang, Y. K., and Chang, H. N. (1997). Production of poly(3-hydroxybutyrate) by high cell density fed-batch culture of Alcaligenes eutrophus with phospate limitation. Biotechnology and Bioengineering, 55(1), 28-32. https://doi.org/10.1002/(SICI)10970290(19970705)55:1<28::AIDBIT4>3.0.CO;2-Z

Thakor, N., Trivedi, U., and Patel, K. C. (2005). Biosynthesis of medium chain length poly(3-hydroxyalkanoates) (mclPHAs) by Comamonas testosteroni during cultivation on vegetable oils. Bioresource Technology, 96(17), 18431850. https://doi.org/10.1016/j.biortech.2005. 01.030

Yu, P. H., Chua, H., Huang, A.-L., and Ho, K.-P. (1999). Conversion of Industrial Food Wastes by Alcaligenes latus into Polyhydroxyalkanoates. Applied Biochemistry and Biotechnology, 78(13), 445-454. https://doi.org/10.1385/ABAB:78:1$3: 445$.

\section{How to cite this article:}

Aditi Dhingra. 2020. Biomedical Applications of Polyhydroxyalkanoates: The Future Polymer. Int.J.Curr.Microbiol.App.Sci. 9(06): 3367-3379. doi: https://doi.org/10.20546/ijcmas.2020.906.399 